\title{
Big Brother Africa and the Promotion of Morality - A Critical Analysis
}

\author{
Ngozi Okpara \\ School of Media and Communication, Pan- Atlantic University, Lagos, Nigeria
}

\begin{abstract}
Big Brother Africa $(B B A)$ is a television reality programme which has an immense followership among the youth population in Africa. However, the programme has on several occasions been criticised for its lack of depth and utmost disregard for the Nigerian and African moral fabric. This paper therefore examined the moral contradictions on display by the housemates. The study employed a descriptive research design and qualitative methodology, which relied mainly on the use of secondary data in the discourse. The findings from the study point to the great disparity between the moral values that are considered acceptable in the Nigerian society and the moral values portrayed in the presentations of the Big Brother Africa reality TV show. The study therefore concludes that $B B A$ is not designed to promote moral values and customs that are acceptable in any given society. It recommends that reality TV entertainment in Nigeria should be developed to reflect the social, cultural and religious values that exist in the cultural and social systems in Nigeria and Africa.
\end{abstract}

Keywords: Reality television, entertainment, morality, Nigeria, Big Brother Africa

DOI: $10.7176 / \mathrm{NMMC} / 86-03$

Publication date: December $31^{\text {st }} 2019$

\section{Introduction}

The concept of reality entails the capture of the state of things as they actually exist in the physical world; it depicts the nature of things in their actual form. The idea behind the conception of reality television as a form of media entertainment is that things are perceived in their real state. Thus, the general understanding of reality television is a wide range of television programmes that aim at being real, factual, as well as entertaining. Roscoe (2001) defines reality television entertainment as programmes where real people are often placed in situations where their lives round-the-clock are recorded as they react to their environments. As a genre of television programme, it involves ordinary individuals, thespians or celebrities, depending on what the show is all about, in assumedly unscripted dramatic or humorous situations (Nwafor and Ezike, 2015). One of the major requirements of reality TV entertainment is that participants voluntarily forfeit claim to private life as long as the programme lasts, because their daily lives are predetermined, programmed by the producers, and are placed on public display. Participants or contestants in such reality TV shows enter to garner fame and monetary gain (Balkin, 2004; Cline, 2018; Sarpong 2018).

In reality television entertainment shows, individuals' actions and reactions in natural or simulated environments are filmed to show their understanding, interpretation and adaption to certain social realities, in which the producers of the programme are interested (Endong, 2014). Roscoe (2001) noted that, in reality TV entertainment, the conventional boundaries between fact and fiction, drama and documentary, and between the audience and the text are blurred. Andrejevic (2004) argued that what sets reality formats apart from news media is their focus on "publicising the private and intimate" and their emphasis on "therapy and social experimentation for the purpose of diversion". From the foregoing, it is obvious that what distinguishes reality entertainment from the conventional media entertainment is its unscripted nature and how events are allowed to turn out in their supposed natural environment (Crane, 2014).

It is believed that reality TV contents are supposed to depict real situations of the moral and living conditions of the people. This throws up many posers as to how the contents of reality TV shows offer Africans any form of physical and human development?

\section{Conceptual Clarification}

\subsection{Reality Television}

Booth (2004) disclosed that what reality TV entertainment refers to as "reality" is basically a recount of activities that had occurred which at times are fraudulent, deceptive and misleading. This "reality" has been criticised on the presentation of an unreal environment in the depiction of reality (Sloame and Roberts, 2011). For example, Big Brother and Survivor reality TV shows create a fabricated environment where the producers determine and control the daily activities of the participants (The Age, 2003).

In essence, what is depicted as reality is a fabricated, highly controlled and determined sequence of events meant to project the plans of the producers. This raises a lot of questions on the reality of the reality show as it can be argued that every live television show is also reality since it depicts an ongoing event. In any case, it is perhaps even more difficult to classify any television content as reality since that supposed reality has already 
been altered by the medium. The television cannot depict a complete environment - a shortcoming that already questions the ideology of reality and the appropriation of meaning to what is seen. To that extent, reality television shows can only be seen as a genre of television broadcast that tends to portray reality in a fabricated setting. As such, the contents that are broadcast to the viewing public are essentially representative of the intents, imaginations and conceptualisation of the producers.

In other words, the reality consumed by the viewers is the interpretation of the imagination of the producers of the show. The participants are usually structured in a simulated environment to achieve the intents of the producers. Hence, reality television shows have sets, activities, rules and other provisions significantly tailored to achieve intended purposes. In this light, one can argue that reality television shows have a significant level of deliberacy and predetermination, and events are not completely spontaneous. Being a type of television programme, one can conclude that the concept of reality show is non-moral.

To classify the concept as either moral or immoral would be to subject the entirety of television programming to the same scrutiny. However, whilst the concept of reality shows may be deemed non-moral, the promoted content can be subjected to a moral debate. Besides, the contents of reality TV entertainment had been identified as promoting unworthy, immoral and uncultured models, transformed into celebrities (Legnan, 2013). This is particularly true of reality TV entertainment shows such as Big Brother Africa where contestants that were seen by viewers to have been involved in immoral conducts are celebrated and crowned winners of the competition hereby glamourising immorality and indecency (Nwafor and Ezike, 2015).

A vivid example is the 2007 edition of the Big Brother Africa won by Richard Bezuidenhout from Tanzania who was accused of distasteful intimate relationship with unconscious Ofunneka Molokwu, a Nigerian participant of the show.

\subsection{Morality}

It is important to establish that morality is perhaps difficult to define because of the religious and cultural dimensions. However, the difficulty in defining the phenomenon does not negate or eradicate its existence. Harman (1977, p. 20) alluded to it: "The fact that there is no obvious way to define ordinary moral terminology in a precise way does not show that there is anything wrong with that terminology." That philosophers, academics and discussants at diverse forums in our societies consider it a discussable subject exemplifies its existence and importance to our sociology and existence. Nevertheless, it is incumbent to provide some operational definitions. Morality is a cultural perception of what is right and wrong and that which constitutes an absolute reference for character and behaviour (Van der Walt, 2003). It is an authoritative code of conduct in matters of right and wrong (Magesa, 2002). It is governed by certain principles such as integrity, dignity, loyalty, honesty, fairness, kindness, compassion and care (Ogundele, 2003). It is considered the method for evaluating human conducts in terms of a system of ideas and practices of a given society, class or social group (Brass and Steidlmeier, 2003). The concept of morality is culturally, socially and religiously based. Hence, what is considered moral in one culture could be immoral in another. What is right in one religion could be wrong in another. Morality is subjective. To capture this, Gert \& Gert (2017) provide a typology of morality, which they described as four aspects of morality - religious morality, morality and nature, individual morality, and social morality. The religious morality is described as the moral prescriptions and expectations derived from the relationship of humans with a supernatural being and predicated on religion (Mbiti, 1975). "Morality and nature" refers the sense of morality that is predicated on how humans act towards natural elements. Individual morality is a higher sense of right and wrong that an individual imposes on himself outside religious, social and natural expectations. Social morality is described as the sense of right and wrong in behavioural expectations in the relationship between an individual and others in the society. Gert \& Gert (2017) further describe social morality as the most important aspect of moral discourse because "it cuts across all of the other aspects of morality" and can be found in any social interaction. Generally, moral codes are like the glue that binds a society (Mawere, 2011). Without moral codes and expectations, a society is likely to degenerate into another animal kingdom as evident in Kammer's conceptualisation of morality. He asserts "the fact that we are moral beings defines our humanness" (Kammer, 1988). We are able to live among other humans in a defined society because of the moral expectations we have of them. Without moral codes, living among other humans in a society will be largely characterised by gross unpredictability. Morality, as a relative concept, is classified into two perspectives: descriptive and prescriptive morality.

Morality in the descriptive viewpoint refers to individual moral inclinations on what is good and acceptable (Simon, 2008). It confers on the individual the right to determine moral values that are acceptable in the society. Gert and Gert (2017) discuss descriptive morality as certain codes of conduct adopted by a society, group or an individual for her own behaviour. Morality from the descriptive angle does not appeal to any sense of objectivity as individuals are the judges in determining which actions can be regarded as morally good or bad.

The normative or prescriptive view of morality views morality from the absolute or universal point of view. Appiah-Sekyere and Awuah-Nyamekye (2012) argue that prescriptive morality acts as a guide to behaviour, 
which rational persons would put forward for governing the behaviour of all moral agents. Since descriptive morality is based on individual points of view, it is subjective and therefore relative to each individual's opinion. The problem with descriptive morality is: if everybody practises their own morality, how would existence and interactions of human persons in society be?

However, prescriptive morality is not always generally applicable to everybody because of individual differences. In some cases, it may contravene the rights of human persons. The dilemma however is about the aspect of morality one should choose. The universality of moral conducts in the modern age is a subject of debate, but within the Nigerian and African contexts, are there common moral conducts and values? This paper will focus on the normative aspect of morality in Africa, particularly Nigeria.

\subsection{Morality within the African Context}

In the African context, morality refers to value systems commonly shared among African cultures. These values are related to the principles of African traditional religion and philosophy (Abiobola, 2001). African morality is based on the traditional practices, culture and religion of Africans, especially sub-Saharan Africans. Van der Walt (2003) explained that traditional African societies have a shared system of moral values, which were used in the bonding of the primordial societies. In traditional West African society, religion serves as a foundation for the philosophy and practice of morality. This is because religious practices are often interwoven with cultural practices of most Africans. Hence, one can comfortably posit that traditional African religion dictates the moral attitude practiced by individuals in the society. This means that African morality flows out of religion, and through this the conduct of individuals is regulated; any break of the moral code is regarded as evil and punishable (Ogugua and Asike, 2015).

Ajayi (2004) further emphasised that early African societies were far from being societies of permissive morality. There were strict moral principles and practices that determined the codes of conduct and what constituted acceptable behaviours. Traditional customs also laid down the code of law which established the nature of right-doings and established punishments and restrictions for offenders. Moral sanctions were mainly religious and metaphysical in nature and were truly effective (Van der Walt, 2003). Gyekye (2011) argued that African moral expectations are independent of religion. Gyekye (2011) argues that no traditional African religion has been determined to be a "revealed religion", in which God directly handed spiritual instructions in an encounter to its founder(s) as obtainable in Christianity, Islam and Judaism. The argument here is that for the revealed religions such as Christianity and Islam, moral instructions are taken as divine instructions that cannot be questioned or disobeyed for the fear of divine retribution.

On the contrary, for the African society, moral codes and expectations are primarily linked with the people's "moral insights". Therefore "African morality originates from considerations of human welfare and interests, not from divine pronouncements" (Gyekye, 2011). Nevertheless, it is impossible to completely separate African morality from religion. As religious or spiritual personalities - as the case may be - become more respected in the society, they tend to use religion as a greater tool for moral sanctions, seeing that the African societies have become increasingly religious.

In Nigeria, various ethnic groups have shared values that can be acknowledged as common and obtainable, regardless of the ethnic background. Moral principles such as honesty, truthfulness, strong family ties and extended family relationships are common to most Nigerian cultures. Majority of the cultures found in Nigeria embrace prudence, justice, communal relations, respect for elders and constituted authorities and proverbs. Decency, the sanctity of life, marriage, hard work, hospitality, a sense of religion, respect for human life and dignity are moral principles also common to most - if not all — the different cultures in Nigeria (Gyekye, 2011; Bewaji, 2004).

Ogugua and Asike (2015) studied moral principles of major traditional cultures in Nigeria and discovered that each has a unique, identifiable principle that forms the basis of its morality. Emphasis of the study was centred on the Yoruba culture, in which it was discovered that the Yorubas place a high premium on the significance of good character as a unique moral principle that signifies responsibility. Ogugua and Asike (2015) opine that the Yoruba people believe each individual must strive to cultivate a good character in order to be able to live in harmony with other members of society. Good character is the highest form of morality in Yoruba culture.

In Tiv culture, the sanctity of marriage as a moral principle is valued (Ushe, 2011). Pre-marital sexual activity is regarded as a taboo that attracts punishment. Any man found guilty of committing such an act with a young girl will be forced to either marry her or pay a certain amount of money to her parents for deflowering her (Ushe, 2011). Among the Tivs, fornication and adultery are considered grievous offences against the society. For them, there is no justification for immoral conducts among the people, thus moral uprightness is an expectation in the culture of Tiv people.

Juxtaposing moral principles obtainable in the Nigerian culture with the common values in African societies, it is unarguable that moral principles across the African continent are largely the same especially across the West 
African sub-region. Morality is a common front that ignites West Africans across the sub-region (Chadha and Anandam, 2011). However, the preceding argument is not unaware of individuals acting in dissonance with these moral expectations. Nevertheless, the fact that some people defiantly act against the moral codes and expectations of the society, without attendant punishment, does not neutralise the existence and appreciation of such moral codes.

Based on the above, a premise can be made that if it is agreed that there are moral codes as well as conducts that are acceptable and regarded as vital to the Nigerian society, are these codes reflected in the development and presentation of reality TV entertainment shows in Nigeria? This study discusses reality television entertainment and morality in Nigeria with particular reference to Big Brother Africa.

\subsection{Morality and Reality TV Shows}

One may ask: "What does morality have to do with reality TV shows?" The explanation adjudged for this is that there are different stakeholders involved in the consumption and production of reality TV shows. This situation already implies the moral dimensions of reality TV shows. Another justification for studying morality and reality TV is the authenticity or reality of reality TV shows (Weiland and Dunbar, 2016). Reality TV shows, in their different genres, throw up a major moral issue. These issues range from authenticity, transparency, integrity, accuracy, trust and responsibility, to other issues of right or wrong particularly from the context of religious and cultural beliefs in Africa and Nigeria in particular. From the literature reviewed and the theoretical frameworks used in this study, reality TV shows bring to light many posers (Cline, 2018, June 22). Do the contents of reality TV shows offer Africans any form of physical and human development? The implication of domination, globalisation and economic exploitation may not be far-fetched in this discourse (Dunning, 2003). Some scholars argued that reality television shows, apart from the moral perspective, also depict issues of neo-colonialism and cultural subjugation by the developed world using media, especially global media and communication (Becker, Hedebro, \& Paldan, 1986; Barker, 1997; Crane, 2014).

Development Media Theory posits that media functions, especially in underdeveloped parts of the world, should be utilised to draw attention to these societies' development plight. Do reality TV shows consumed by Nigerians offer such important aspects of development? Again, the media has a huge responsibility to provide contents which - along with entertaining - address cogent problems of the society. Thus, the second theoretical framework corroborates the position of development media theory to emphasise the need for a type of entertainment media that addresses the play factor as well as fundamental aspects of human development, which complement and shape positive structural and physical development of any society. The findings of this work will help to fill the important gaps of reality TV shows generally and particularly in Nigeria.

\subsection{Big Brother Africa Reality TV Show and Morality}

Big Brother was created by the Dutch television network, Veronica, in 1999 but was later overtaken by the network Endemol (Drotner, 2002). The first edition of the programme in the Netherlands was so successful that "four million out of 15 million Dutch people saw final episode on 30th December 1999" (Drotner, 2002), representing nearly $30 \%$ of the total population of the country. Owing to the success of the programme in the Netherlands, the franchise was first sold to other European countries, and later to South America, America, Asia, and Africa. This paper focuses on the African version, Big Brother Africa. Big Brother is a reality television show in which people are brought together in a large house secluded from events happening outside their location. In-house television cameras as well as personal audio microphones continuously monitor contestants during their entire stay in the house.

The theme of Big Brother reality TV show is usually centred on four elements, which are the environment in which contestants live, the elimination system, the task set by the editorial team, and the diary room (Andrejevic, 2004). With an estimated viewership of more than forty million across Africa, Big Brother Africa $(B B A)$ can be regarded as having an unimaginable influence on the moral standards of youths (Nwafor and Ezike, 2015). In Nigeria, $B B A$ has become one of the most popular reality TV shows and this popularity has drawn the attention of scholars and media analysts to examine the moral implications of the programme, the contestants, and the values it portrays.

The development of $B B A$ was built on the idea of promoting mutual co-existence among African youths regardless of their nationality, background, ethnicity, religion and sex (Endong, 2014). It was developed to refute claims by western countries that Africans are divided by ethnic and religious inclinations (Nwafor and Ezike, 2015). One of the major goals of $B B A$ is to promote the rich African cultural heritage (Ozule and Mohammed, 2013). Although, the intent of the producers of $B B A$ was Pan-African at the onset, the show seems to have assumed an anti-African posture on moral basis.

This can be perceived in the way housemates display their characters and interact on the show, which obviously raise insinuations about whether the contestants represent themselves or their respective countries. Commenting on the unafricanised conduct of BBA contestants, Novia (2013) argued that although the producers 
of $B B A$ disclosed that contestants on $B B A$ represent themselves not their country, the truth remains that each contestant is an ambassador of their respective countries. In contrast, it has been put forward in an argument that $B B A$ contestants do not and cannot in entirety represent their countries. This is due to the complexity and diversity of the African society.

Therefore, $B B A$ contestants are reflections of their personal ideals and values. In a similar vein, Ige (2015) argued on the instance of the sexual relationship that existed between Betty, an Ethiopian contestant, and Bolt, a Sierra Leonean, in the Big Brother Chase house that categorising an individual's action on $B B A$ as a national action is fallacious. Nevertheless, individuals only subscribe to participate in the programme having full knowledge of what it entails and take full responsibility for their actions. In essence, the show is used to build up a perfect start to contestants' careers in the entertainment industry. Therefore, their actions are independent of their national characters.

A cross section of discourse from $B B A$ fans blog (www.afanmedia.blogspot.com.ng) emphasised the irrelevance of $B B A$ to the African cause. The fans were asked whether $B B A$ was preserving the African heritage. Two hundred fans responded to the question and it was affirmed that $B B A$ does not in any way project or preserve the African culture, rather it suppresses it with the infusion of Western values and morals (Agbuza et al, 2013). Appiah-Sekyere and Awuah-Nyamekye, (2012) observed that $B B A$ has a negative influence on youths as it exposes them to semi-nude scenes and vices that are injurious to their social, psychological, and educational development. Ojoko (2013) argued that $B B A$, as a reality show, does not portray any educational values to the viewers and as such cannot portray Africa's cultural heritage.

A fan wrote on his Facebook page:

"The $B B A$ is about immoral behaviour and that is why it attracts a lot of

fans ... There is no single thing to learn from the programme, they just promote sex and immorality..." (Ajibade, 2013).

Buttressing the ills of $B B A$, he stated that the show does not in any way reflect the traditional African heritage, which includes art, folklore, religion etc. Having a divergent view from this, Bonaventure (2014) expressed that $B B A$ is simply a reflection of people's way of life in their environment. He further explained that the idea of $B B A$ was not to promote the African culture, rather it was meant to show how people from diverse backgrounds relate with each other and build an interpersonal relationship.

\section{Theoretical Framework}

\subsection{Social Responsibility Theory of the Media}

Social Responsibility Theory of Mass Media started in the mid-20th century and is used mostly by the developing and least developed countries. The theory made its entrance into limelight with the Commission on the Freedom of Press commissioned in the United States in 1949 (Hutchins Commission on the Freedom of the Press, 1947). The theory was formalised by Siebert, Peterson and Schramm in 1956 in their book, Four Theories of the Press. It proposes total freedom for the press with no censorship. However, it also recommends that media be regulated in line with their social responsibilities and obligations (Skjerdal, 1998). Proponents of the theory opine that media content should be filtered through public obligation and interference.

The theory replaced Libertarian Theory with the view that libertarianism was outdated, but borrows some elements of the Authoritarian Theory of the Press. Social Responsibility Theory strives to proffer a mean between two extremes for the media - complete freedom with no restrictions and complete government regulations. At the emergence of this theory, professionalism in media took a turn for good; practitioners took media business more seriously. The most important aspect of the social responsibility theory is its recognition of the people and the responsibility of the media in the society within which it operates.

Social responsibility theory considers the media as for the people and society. The media is taken as a platform for the voiceless to have a voice and is considered not as an end, but a tool for social development. Hence, the objectives of media are to inform, document, analyse, interpret, mediate and mobilise by creating and finding solutions. As a result, the media should develop and adhere to a code of conduct created by them and develop respected standards in practice for the betterment of society (Lambeth, 1992; Merritt, 1995; Lu, 2012). In such a situation, the contents provided by the media are analysed and interpreted in a way that enables the people to consume accurate, truthful and uplifting offerings. Ultimately, this encourages social harmony by exposing social evils and discouraging bad conducts. The main thrust of this theory in relation to the study is the recognition of the media as a self-regulating institution (West and Turner, 2004; Littlejohnn and Foss, 2008; Dominick, 2009). In the light of this paper, one would observe that the media seems to be more interested in offering entertainment without proper attention to its responsibility to build a society conscious of good behaviour. The media has the responsibility to regulate itself as a way of promoting social harmony and societal development, which is its social function. 


\subsection{Development Media Theory}

The development media theory was propounded by McQuail (1987). It was a theory developed for the growth of mass media in developing countries. The theory canvasses media support for an existing government and its efforts to bring about socio-economic development (McQuail, 1987, 1994). It argues that until a nation is wellestablished and its economic development well underway, media must be supportive and assist in implementing the socio-cultural policies that will advance development.

Development media theory seeks to nurture the autonomy of the developing nations and gives special emphasis to indigenous cultures, values and traditions. It encourages the media to incorporate the values and norms of its immediate society into its programmes. It emphasises the supremacy of local content in media programming (McQuail, (2005). Furthermore, the theory views the media as an agent for inculcating the moral values and principles evident in the society into citizens.

The development media theory assumes that the media should therefore prioritise the coverage of those areas that influence the lives of the people. In other words, content should be development-driven and should centre on socio-economic and political lives of the people. The theory posits that the mass media should accord priority politically, geographically and culturally to solidarity and indigenous development among developing countries (Folarin, 2005).

Therefore, the media in Nigeria is saddled with the responsibility of entrenching moral principles that are peculiar to the Nigerian society in its programming and broadcast. With respect to the broadcast of reality television in Nigeria, the media can be said to have incorporated immoral values especially in Big Brother Africa as scenes of nudity, excessive smoking, drinking and bigotry characteristic of the show are not acceptable within the Nigerian culture.

\section{Methodology}

The study uses descriptive research designs and qualitative methodology. Data were collected from secondary sources, which included books, journals, magazines, newspapers and the internet.

\subsection{Data Presentation Nudity}

The fashion sense of the contestants during the show leaves a lot to be desired as the female contestants are dressed in semi-nude apparels that expose sensitive parts of their body. In addition, the "Shower Hour" is another disturbing aspect of the show. This has been the major high point of $B B A$ 's criticism as Legnan in Nwafor and Ezike (2015) condemns the show for its high portrayal of nude women, which in a way debases the dignity of womanhood and sends a wrong impression of the African woman to the world. Showing the nude bodies of contestants does not align with the Nigerian cultural values and it reduces human dignity.

\section{Immoral behaviour}

Drunkenness, sex, bullying, wild parties and smoking have all been frequently shown on the Big Brother Africa reality TV show. During the second season, second runner-up, Ofunneka Molokwu, a Nigerian participant was allegedly assaulted sexually by Richard Dyle Bezuidenhout from Tanzania when all the housemates were drunk. The producers of the show kept mute on the incident and the 'suspect' was later named the winner of the show in 2004. Other contestants such as Meryl (Namibia), Kweku (Ghana), Bhoke Egina (Tanzania), Ernest Wasake (Uganda), Beverly Osu (Nigeria) and Angelo Collins (South Africa) have all been identified as having engaged in sexual activities openly while in the $B B A$ house.

\section{Audience}

Due to the possibility of unplanned activities or displays occurring in the course of the show, it is rated 18 . However, there are fears that children may still have access to the programme. This is particularly a moral issue because clips of the show are online and can easily be accessed by minors who might not be allowed to watch the programme at home. It is unethical for minors who are not yet moral agents to consume such media contents. Beyond the television broadcast, in a world of new media convergence where teenagers below the prescribed age are very much active on social media, the contents of the programme cannot be exclusive to television broadcasts alone. Clips of the show, especially raunchy moments, are usually shared on social media by enthusiastic viewers, which ultimately expose the vulnerable population to the rated contents.

\section{Commoditisation of the human person}

The Big Brother Africa reality TV show is a game with a certain amount of money stated as the reward for the winner. As a result, some of the contestants often act in certain ways that are not in line with their usual character, in order to remain in the $B B A$ house and win the prize. In other words, contestants are not completely spontaneous in their behaviour, but choose to act in certain ways as a strategy to emerge victorious. This can be described as a form of commoditisation of the human person. In addition, it can be argued that the producers of $B B A$ only view these contestants as necessary features in order to make money. By doing this, they are treating these contestants as a means to an end, which is a practice that is against the dignity of the human person. 


\section{Violation of the common African/Nigerian belief}

The co-existence of men and women in the same room is contrary to African culture and by implication, the Nigerian culture. In most African societies, it is deemed inappropriate for men and women to live together except they are married or siblings. The Big Brother house, on the contrary, houses both men and women from different countries and lifestyles together; sometimes, they even sleep in the same rooms.

\subsection{Discussion of Findings}

Comparing this with the level of morality obtainable in the Nigerian society, it would suffice to note that $B B A$ does not subscribe to the moral values of the Nigerian culture (Endong, 2014). Based on findings, the contents displayed in $B B A$ can be criticised on the grounds of its unethical subscription to values that are not known to be Nigerian and the degradation of the moral standards of the Nigerian culture. The Nigerian culture is entrenched with values that impose on the individual socially acceptable ways of behaving in order to achieve social harmony, cooperative living, justice and fairness.

Strengthening the discussion, the discovery from the study revealed that the show was characterised by nudity, sex and vulgarism. This supports the view of Ojeifo (2017) which further disclosed that $B B A d o e s$ not in any way transmit good moral values to our youths. He described the show as one that places high premium on the celebration of immorality. In addition, Abati (2017) commented that Big Brother Africa, and its Nigerian equivalent Big Brother Nigeria, promote base values, which are adultery, prostitution, love of money, nudity, and sex. Furthermore, Abati stated that the organisers of the show made money by devaluing other human persons and in the process, they made alcoholism and pornography a legitimate sport (Abati, 2017).

\subsection{Conclusion}

The study examined the relationship between reality TV entertainment and morality, with particular reference to Big Brother Africa. The study utilised a descriptive research design and qualitative methodology, which relied mainly on the use of secondary data in the discourse. The findings from the study point to the fact that there is a great disparity between the moral values that are considered acceptable in the Nigerian society and the moral values portrayed in the presentations of the Big Brother Africa reality TV show. In other words, the visual contents of the Big Brother Africa show do not in any way reflect the social and cultural norms that are essential to the sustenance of the Nigerian society. The study therefore concludes that reality television entertainment should be designed to promote moral values and customs that are acceptable in any given society. The relevance of $B B A$ in Nigeria cannot be disregarded, but the show can include morals that are acceptable in Nigeria. This is because of the general belief by various stakeholders that $B B A$ promotes values that are not in conformity with the Nigerian cultural and moral system.

\subsection{Recommendations}

Based on the foregoing, the study recommends that:

- Media literacy and moral instruction should be included in curriculum at all levels of education. Parents should also be electrate; this is because knowledge of electronic communication has pushed literacy to electracy. Therefore, being able to read and write is no longer a means of measuring a person's literacy. Understanding the rudiments of new media will go a long way to educate parents, children, and nonmedia persons on how the media work.

- $\quad$ Reality TV entertainment in Nigeria should be developed to reflect the social, cultural and religious values that exist in the cultural and social systems in Nigeria and Africa. Moral guidelines on the expected conducts of housemates should be established and enforced. Sanctions should be applied to housemates or contestants that behave or act in ways contrary to the stipulated guidelines.

- Media contents should be fashioned in a way that media programmes are appealing to the target audience without being vulgar and offensive. This calls for creativity on the part of programme producers to churn out programmes with contents that are morally inclined yet have the savour to attract appropriately. Media should strive to produce contents that are moral, yet popular.

- Media content developers, local or international, professional or non-professional, should uphold the gatekeeping function of the media as well as other media ethics and principles. Media guidelines and regulations should be enforced by organisations set up for such functions such as the National Film and Video Censors Board (NFVCB), National Broadcasting Commission (NBC), among others.

- Media contents can also be used as tools to solve the myriad of problems facing Nigeria and other African countries. Ideas from development media theory used for this study can be applied to solve problems of corruption, religious fundamentalism, ethnicity, human trafficking, prostitution, divorce, family problems, terrorism and other such challenges confronting Nigeria and Africa as a whole. Appropriating ideas from the development theory, the study recommends that reality television shows in Nigeria should be developed to reflect the social, moral, cultural and religious values that exist in the 
system.

\section{References}

Abati, R. (2017). Big Brother Nigeria: Between Morality and Entertainment. https://guardian.ng/art/big-brothernigeria-between-entertainment-and-morality. Retrieved on $14^{\text {th }}$ December, 2017.

Abiobola, K. (2001). "Spirituality and Applied Ethics: An African Perspective." West Africa Review, 3 (1) 1. http://www. westafricareview.com/vol3.1/abimbola.html. (accessed 22 May 2015).

Agbuza, A., Mohammed, J., Oyewole, F., and Aiyejino, K. (2013). www.afanmedia.blogspot.com.ng/2013/04/big-brother-africa-and-african-culture.html. Retrieved on $14^{\text {th }}$ December, 2016.

Ajayi, S.K. (2004). Cultural values, virtue and individual personality. 4th ed. Mushin, Lagos: Pitman Ltd.

Ajibade, C. (2013). Letter to DSTV on BBA from African Youth. Retrieved from https://www.facebook.com/dstvng/posts/letter-to-dstv-on-bba-from-african-youthi-urge-and-plead-with-allafrican-youths/10151665258684675/.

Andrejevic, M. (2004) Reality TV: The Work of Being Watched. Maryland: Rowman \& Littlefield Publishers.

Appiah-Sekyere, P. \& Awuah-Nyamekye, S. (2012). Teenage pregnancy in the life and thought of the Akan: Moral perspectives. Sociology Study, Vol. 2, No. 2, p. 129.

Balkin, K.F. (ed). (2004). Reality TV [Electronic Version]. Retrieved November 28, 2004 from http://www.enotes.com/reality-tv/952.

Barker, C. (1997). Global Television - An Introduction. Oxford: Blackwell Publishers. Bauman, Z. 2003. Society Under Siege. Cambridge: Polity Press.

Becker, J., Hedebro, G., \& Paldan, L. (eds.) (1986). Communication and Domination. New Jersey: Ablex Publishing Corp.

Bewaji, J. A. I. (2004). Ethics and Morality in Yoruba Culture. In K. Wiredu (ed.). Companion to African Philosophy (pp. 396-403). Malden, MA: Blackwell Publishing.

Bonaventure, A. (2014). To Stop Nigerians from participating in the Big Brother Africa Reality TV show. https://www.change.org/p/david-alechenu-bonaventure-mark-to-stop-nigerians-from-participating-in-thebig-brother-africa-reality-tv-show. Retrieved on $14^{\text {th }}$ December, 2017

Booth, W., (2004). Reality is Just an Illusion. Retrieved from http://www.washingtonpost.com/wpdyn/articles/A53032-2004Aug9.html?noredirect on $2^{\text {nd }}$ October, 2016

Brass, B. and Steidlmeier, G., (2003). Reality blights. Retrieved 2 $2^{\text {nd }}$ October, 2016 from http:// facstaff.Bloomu.edu/brass/abc.htm

Chadha, K. and Anandam, K. (2017). Media Imperialism Revisited: Some Findings from the Asian Case. Media and Culture Society. Retrieved from https:/themediastudentsblog.wordpress.com/2017/10/29/readingmedia-imperialism-revisited-some-findings-from-the-asian-case/

Cline, A. (2018, June 22). Ethics and Reality TV: Should We Really Watch? Retrieved from https://www.thoughtco.com/ethics-and-reality-tv-4016356

Crane, D., (2014). Cultural globalization and the dominance of the American Film Industry: cultural policies, national film industries, and transnational film. International Journal of Cultural Policy, 20(4), 365-382.

Dominick, J.R. (2009). The dynamics of mass communication, media in the digital age, Tenth edition. Boston: McGraw-Hill.

Drotner, K., (2002). New media, new options, new communities? Towards a convergent media and ICT research Nordica Information, pp. 11-22.

Dunning, J.H., (2003). "The Moral Imperatives of Global Capitalism: An Overview.” In J. H. Dunning (Ed.), Making Globalization Good - The Moral Challenges of Global Capitalism (pp. 12-40). Oxford: Oxford University Press.

Endong, F.P. (2014). Audience westernization as a threat to the indigenization model of media broadcast in Nigeria. Vol. 6(8). Pp. 121-129, DOI: 10.5897/JMCS2014.0400.

Folarin, B. (2005). Theories of Mass Communication. College Press and Publishers Ltd, Ibadan.

Gert, B. \& Gert, J. (2017). The definition of morality. (E. N. Zalta, Editor) Retrieved January 31, 2018, from The Stanford Encyclopedia of Philosophy: https://plato.stanford.edu/entries/morality-definition/

Gyekye, K. (2011). African ethics. The Stanford Encyclopedia of Philosophy. (E. N. Zalta, Ed.) Metaphysics Research Lab, Stanford University.

Harman, G., (1977). The nature of morality: An introduction to ethics. New York: Oxford University Press.

Hutchins Commission on the Freedom of the Press. (1947). A free and responsible press. Chicago: University of Chicago Press.

Ige, T. (2015). Why Your Children Should Avoid Davido's Video “Fans Mi”. In Vanguard (Nigerian Newspaper, June 2015) www.vanguardngr.com/2015/06/ why-your-children-should-avoid-davidos-video-fans-mi. Accessed 28 September, 2016 
Kammer, C.L. (1988). Ethics and liberation: An introduction. London: SCM Press.

Lambeth, E., (1992). Committed journalism: An ethic for the profession. Bloomington: Indiana University Press.

Lengnan, T., (2013). BBA: South African, Angelo, in shameful romance with Nigeria's Beverly. Retrieved from www.peoplesdailyng.com on October 10, 2016

Littlejohnn, S.W. and Foss, K.A., (2008). Theories of Human Communication, Ninth Edition, Belmont, CA: Thomson Wadsworth.

Lu, T. (2012) Media discourse of corporate social responsibility in China: a content analysis of newspapers, Asian Journal of Communication, 22:3, 270-288, DOI: 10.1080/01292986.2012.662515

Magesa, L. (2002). African religion: The moral traditions of abundant life. New York: Orbis Books.

Mawere, M. (2011). Moral degeneration in contemporary Zimbabwean business practices. Bamenda: Langaa RPCIG.

Mbiti, J.S. (1975). An Introduction to African Religion. London: Heinemann

McQuail, D. (1987). Mass communication theory: An introduction. London: Sage Publications.

McQuail, D. (1994). Mass communication theory. An introduction [3rd edition]. London: Sage

McQuail, D. (2005). McQuail's Mass Communication Theory. (5th edition). London: Sage Publications.

Merritt, D. (1995). Public journalism and public life. Why telling the truth is not enough. Hillsdale, N.J.: Lawrence Erlbaum Associates.

Novia, C., (2013). Charles Novia's thoughts on \#BBATheChase and Beverly Osu. Retrieved from http://thenet.ng/read-charles-novias-thoughts-on-bbathechase-and-beverly-osu/

Nwafor, K.A. and Ezike, M.O. (2015). Viewership of big brother Africa reality tv show and its influence on the moral conduct of undergraduate students in Ebonyi State University, Abakaliki, Nigeria. Global Journal of Arts Humanities and Social Sciences Vol.3, No.5, pp.1- 15.

Ogugua, P. and Asike, J.C., (2015). Nigeria Traditional Moral Values in the Context of Globalization: Approach of Justice and Responsibility. Retrieved $2^{\text {nd }}$ October, 2016 from https:/www.ajol.info/index.php

Ogundele, O.J.K. (2003): Roles of Social Responsibility and Ethics in the Environment, Conference proceedings, $11^{\text {th }}$ National Conference of Environment and Behaviour Association of Nigeria, Federal University of Technology, Akure, pp 304-311

Ojeifo, E. (2017). Big Brother Nigeria: Between entertainment and morality. Retrieved from https://www.premiumtimesng.com/features-and-interviews/229006-big-brother-naija-entertainmentmorality.html.

Ojoko, L. (2013). BBA Africa: Matter Arising. Retrieved on 25 January, 2018 from http://www.nairaland.com/1327269/bba-africa-matters-arising.

Ozule, K. and Mohammed, L. (2013) Big Brother Africa and the African culture. Retrieved on 12 June, 2014 from afanmedia.blogspot.com.

Roscoe, J., (2001). Big Brother Australia: Performing the 'real' twenty-four-seven. International journal of cultural studies, 4(4): p473-488.

Sarpong, S. Soc (2018) 55: 53. https://doi.org/10.1007/s12115-017-0210-1 (Pushing the Boundary: are Reality TV Shows Ruffling Feathers in Africa?)

Siebert, F., Peterson, T.B., Schramm, W. (1956). Four Theories of the Press: The Authoritarian, Libertarian, Social Responsibility, and Soviet Communist Concepts of What the Press Should Be and Do. Illinois: University of Illinois Press

Simon, B., (2008). Oxford Dictionary of Philosophy. $2^{\text {nd }}$ Edition. Oxford: Oxford University Press.

Skjerdal, T., (1998). Social responsibility and communitarian ethics in the media: Is there a difference? Centre for Cultural and Media Studies, University of Natal. Unpublished paper.

Sloame, J. and Roberts, S., (2011). Most Vile Stars on Reality TV: The Uglist Meansest and Most Violent of them all. Retrieved on $25^{\text {th }}$ November, 2018. From https://www.nydailynews.com/entertainment/tv/hatedreality-tv-stars-gallery-1.79084?barcprox $=$ true \&barcprox $=$ true

The Age, (2003). Surviving and Thriving. Melbourne. Retrieved on 25 November, 2018 from https://www.theage.com.au/entertainment/tv-and-radio/surviving-and-thriving-20031113-gdwq7i.html

Ushe, M. (2011). Role of Traditional African Moral Values in the Development of Nigeria. Journal of Sociology, Psychology and Anthropology in Practice Vol 3, No. 2.

Van der Walt, B.J., (2003). Understanding and rebuilding Africa. Potchefstroom: The institute for contemporary Christianity in Africa.

Weiland S.J. and Dunbar, K., (2016) What's real about reality television? Journal of Mass Communication \& Journalism 6: 308

West, R. and Turner, L.H. (2004). Introducing Communication Theory, Analysis and Application, Second Edition, Boston: McGraw Hill Inc. 